\title{
Analyzing the Peace through Tourism Concept: The Challenge for Educators
}

\author{
Carmen Jimenez, Jan te Kloeze* \\ Wageningen International Centre of Excellence on Development of Sustainable Leisure, Elzenpas 2, 6666 HE Heteren, The Netherlands \\ *Corresponding Author: jan.tekloeze@wice-dsl.nl
}

Copyright (C) 2014 Horizon Research Publishing All rights reserved.

\begin{abstract}
It is fair to say that tourism has become into one of the largest and faster growing industries of the planet. The tourism sector represents 3-5\% of the GDP, jobs and investment in first world countries, and up to $30 \%$ in developing countries. As tourism continues to gain economic importance as a source of foreign exchange, so does the debate about its positive and negative effects in contemporary literature. There are several authors stating that international traveling promotes understanding and trust among people from different backgrounds. This line of thinking has brought up to surface the concept of Peace through Tourism. Sometimes regarded as an over-statement, this concept is a worth mentioning topic of debate. The present paper discusses both views on the subject; the supporting arguments defending it and the arguments stating that it is rather a naïve conception of what tourism really is. The aim is to clarify the real scope of the notion of Peace through Tourism and propose a rationale and working concept for tourism educators. In addition, the paper presents some of the challenges that still lay ahead for tourism educators dealing with this topic.
\end{abstract}

Keywords Tourism, Peace, Education, Rationale, Working Definition

\section{Introduction}

Tourism is a flourishing industry in terms of growth and economical importance worldwide, especially in developing countries. It is calculated that tourism represents 3-5\% of the GDP, jobs and investment in industrialized countries, and up to $30 \%$ in developing countries (WTO, 2006a). Although it has faced several short falls in the last years due to the SARS epidemic outbreak, September $11^{\text {th }}$, and the Iraq war among other events, tourism has proven to be a very resilient industry. Furthermore, the substantial growth of the tourism industry throughout the years portraits it "as one of the most remarkable economic and social phenomena of the past century" (WTO, 2005: pp. 104). This statement is clearly supported by examining the numbers and statistics related to world tourism. International arrivals have increased from 25 million in 1950, to 691 million in 2003, and according to the World Tourism Organization's vision forecasts, will rise to one billion in 2010 and will continue to growth to reach 1.6 billion by the year 2020 (WTO, 2005).

The above figures portrait tourism as a powerful economic industry with future, but is it also a peace force? Authors like D'Amore (1988) and Kelly (2006a) (founder and member of the International Institute for Peace Through Tourism (IIPT) respectively) support the concept of Peace trough Tourism, suggesting that tourism can act as a means to promote cultural understanding by bringing people from different cultural backgrounds together, and thus foster peace.

According to the IIPT, the scope of the peace through tourism concept is broad, as it can be observed in its mission statement:

'... to fostering and facilitating tourism initiatives which contribute to international understanding and cooperation, an improved quality of environment, the preservation of heritage, and through these initiatives, helping to bring about a peaceful and sustainable world.

It is based on a vision of the world's largest industry, travel and tourism - becoming the world's first global peace industry; and the belief that every traveler is potentially an 'Ambassador for Peace'.

A primary goal of IIPT is to mobilize the travel and tourism industry as a leading force for poverty reduction' (IIPT, 2006)

According to this vision, the notion of Peace through Tourism encompasses poverty alleviation, international understanding, preservation of heritage, protection of the environment, and sustainability. Indeed this is a very positive way of looking at tourism and it is a tempting formulation to highlight the positive roles of travel in regards to peace. However taking this "broad" definition as a working concept for Peace through Tourism education is perhaps too optimistic (not to say naïve), given that this is not an uncontestable proposition. There is need of clarifying and rationalizing the scope of the concept, analyzing the positive and negative impacts of tourism in order to validate this optimistic view. 
Furthermore, there are opposing arguments questioning the IIPT's claim of tourism promoting peace, stating that tourism is not necessarily a peace generator, but merely a beneficiary of peace (Litvin, 1998). Overcoming these contrasting positions and finding a working concept of Peace through Tourism, is one of the challenges still ahead for tourism educators dealing with this topic. This paper presents the arguments of both positions, to later examine the validity of the 'broad' Peace through Tourism concept. The aim is to propose an objective rationale and working concept of Peace through Tourism for educators. The final section discusses some of the opportunities, difficulties and challenges for tourism educators working in this area.

\section{The Peace through Tourism Concept}

To begin with the analysis it is necessary to clarify the concept in question. Peace through Tourism refers to the reduction and hopeful elimination of conditions that lead to violence (Kelly, 2006a). This concept stands of the belief that these conditions can be ameliorated or avoided through the channel of tourism (Kelly, 2006a). When talking about tourism as channel it refers to the virtue of traveling promoting international understanding. D'Amore (1988) outlines the strategic role that tourists can plan by explaining the theory of two tracks of diplomacy proposed by Davidson and Montville (1981-82). Track one diplomacy is the one that occurs officially with government to government interactions, and track two diplomacy takes places in people to people relations. Tourism works at the track two diplomacy level, creating the opportunity for tourists to get first hand experiences from culturally different hosts, and become aware of their personalities, beliefs, aspirations, culture, politic inclinations and life perspectives (D'Amore, 1988).

The notion of peace used in this conception is 'positive peace'. Positive peace refers not only to the absence of violence (negative peace) but includes equity, social justice, harmony, cooperation among humans from different cultural patterns, and absence of cultural and structural violence (Sandy \& Perkins, 2002).

\section{Tourism as Beneficiary of Peace}

"Tourism is genuinely acknowledged as a peace industry" (Crotts 2003: pp. 92); when Crotts wrote this, he was talking about the need of a peaceful context for tourism to take place. History has largely supported this view, with events such as terrorist attacks and war hampering tourism flows in before well-off destinations. Experiences such as the 1991 Gulf War show us that when confronted with safety concerns about their destination, travelers either choose safer destinations or simply avoid traveling (Sonmez, Apostopolus \& Tarlow, 1991).

The need of Peace for Tourism to flourish can be better illustrated analyzing the case of Northern Ireland. The region of North Ireland was historically one of the less favored provinces in the UK. Mainly dedicated to agriculture in past times, this area has suffered not only from the decline of traditional industries, low employment levels, and periods of recession and depression; but also from ongoing violence and conflicts, which picked in the 1960s and 1970s giving this region an image of a 'land torn by conflict' (Ryan, et al., 1996: pp. 51). The root of the conflict was the clash between Unionists (mainly Protestants wanting to remain part of the United Kingdom) and Nationalists (mostly Catholics wanting Northern Ireland to be part of the Irish Republic), rivalry that gave pace to the apparition of violent sectarian lines (Anson, 1999 and Darby, 1995).

Tourism was greatly affected by violence and terrorism in Northern Ireland. Tourist arrivals dropped from a peak of 1.080 .000 in 1960 , to 435.000 in 1972, and 930.400 in 1988 (NITB, 1997). Conflict remained somehow constant with several failed attempts of establishing peace until 1994, when finally, a political negotiation managed to cease fire (Anson, 1999 and Darby, 1995).

Although the cease of fire lasted only 18 months, this time window gave tourism a chance to flare again. In 1995 tourism numbers raised by $20 \%$, pure holiday visitors increased up to $68 \%$, and the visitor spending was up to $17 \%$, in relation to 1994 statistics (O'Neil, 1997 cited in Anson, 1999). After the end of the cease of fire, tourism figures dropped back again (from 1.557.000 in 1995, to 1.415 .000 in $1997)$ but remained higher than pre-cease of fire numbers (1.254.000 in 1992 and 1.262 .000 in 1993) (NITB, 2002). Statistics point out, that the peace dividend did benefit North Ireland's tourism, and constitutes a great example of tourism taking advantage of a peaceful context. However, this case suggests that tourism is not a peacekeeping force by itself.

A good example of tourism's vulnerability to war is the former Yugoslavia. At the end of the 1980s, tourism was an activity of strategic importance in this Federation, accounting for $70 \%$ of all employment (UN, 2002). However, the electoral results of the 1990 elections marked the beginning of Yugoslavia's disintegration, where the separatist movements initiated an era of war and conflict between the separating-new countries marked by the confrontation of Bosniaks, Serbs and Croats (CES, 2004).

The new state of war, unfavorable political situations and violent confrontations seriously damaged former Yugoslavia's tourism industry. The before high tourist figures dropped from 22.903.000 tourist nights in 1988 to 12.082.000 in 1997 (UN, 2002). Tourist arrivals fell from 5.696.000 in 1988 to merely 1.742 .000 in 1999 (UN, 2002). These figures demonstrate that even in countries where tourism constitutes one of the main sources of income, tourism alone cannot secure peace.

The examples of Ireland and Yugoslavia, added up to events like September $11^{\text {th }}$, the Bali bombings, and Israel's recent episodes of civil violence, shows us that tourism cannot be regarded as a peacekeeping tool. Moreover, it is considered that less diversified economies relaying on 
tourism, are very vulnerable to seasonal effects, regional conflicts, natural disasters, and unexpected events such as terrorist attacks and war (Neto, 2003).

Evidence shows that tourism is not likely to act as peacekeeping guaranty, but could it genuinely contribute to foster peace? Litvin (1998) (in one of the few formal articles questioning the peace and tourism proposition) criticizes this notion:

'It is my belief that the tourism creates peace camp has a serious problem with the basic research axiom that distinguishes between co-relational and causal relationships. Does tourism create peace or is tourism, along with many other industries, a fortunate beneficiary of peace? ... [ ] ... as tourism is never successful in the absence of peace, it cannot, therefore, be a generator of peace' (Litvin, 1998: pp, 64, 66)

Litvin explains his argument stating that even when interaction and sharing between tourists and locals happen, real understanding is not likely to take place. This is an arguable point since there are a number of studies suggesting that tourism can reduce tension and suspicion by creating opportunities of interaction and thus, a better understanding of the other (Guo, et al., 2006; Kim \& Prideaux, 2006, Noy, 2004 and Cho, 2006). However, evaluating this critic of the Peace through Tourism notion is not pertinent yet without first exploring in depth the arguments that support the tourism and peace proposition.

\section{Tourism as Tool to Promote Peace}

As already mentioned above, the Peace through Tourism proposition stands on the belief that cultural understanding can promote attitude change and thus facilitate peace. Stereotypic beliefs are considered to be the root of unfavorable attitudes towards the culturally different (Dovido, et al. cited in Spencer-Rodgers \& McGovern, 2002). Stereotypes are associated with the lack of personal experiences and miss-information about the culture and reality of the other. 'It is when people perceive themselves to be different from others that fertile conditions for discord emerge' (Kim \& Crompton, 1990). It should be clarified that is not the realization of being different that leads to conflict; it is the misconception of the difference. The acceptance of cultural difference can be a positive and enriching value. Therefore, dissolving bad stereotypes and giving people the chance to familiarize themselves with culturally different persons can help prevent conflicts and foster peace. It is with this reasoning that several authors suggest that tourism is a means to promote intercultural understanding (Kim \& Crompton, 1990; Jafari, 1989; Kelly, 2006b; Higgins-Desbiolles, 2003; and Litvin, 2000).

Spencer-Rodgers \& McGovern (2002) studied the psychological impact of intercultural communication barriers on intergroup attitudes, surveying American students about their perception of foreign students. Their study indicated that negative stereotypes can be addressed by promoting contact with foreign students, stressing on the fact that frequent contact alone not always leads to intercultural communication and that further information should be given along with contact experiences (Spencer-Rodgers \& McGovern, 2002).

In a similar venture, Horencyk \& Bekermand (1997) investigated the effects of intercultural acquaintance and structured group interaction on group perceptions. They interviewed Jewish American youngsters visiting Israel, asking them to rate their perceptions of Jewish teenagers in Israel along with the perception they thought Jewish teenagers would have of them. The findings of the study revealed that the initial unfavorable rates American Jewish teenagers had of Israeli Jewish teenagers, changed to more positive attitudes and rates, after a five weeks study trip in Israel.

Although initially developed to help understand factors shaping people's behavior and perceptions, both of the above studies support the idea of intercultural contact and experiences helping to dissipate stereotypes and misconceptions. In the light of this findings and considering tourism as means of contact, it is possible to say that it does foster understanding. However, it is necessary to recognize that intercultural understanding in tourism is not always granted, as not all types of tourism create opportunities of real contact with the hosts. There are three relevant conditions needed for cultural understanding to take place: first, the type of tourism needs to offer these 'cultural understanding opportunities' (small scale tourism), second, the tourist needs to be willing to interact with the host and be interested in getting to know their culture and hearing what they got to say (conscious or ethical traveler), and third, the host community must be willing to interact and share its cultural view with foreign tourists (welcoming hosts).

Obviously, the three above conditions are not present in all types of tourism. When talking about tourism becoming a mass phenomenon, Krippendorf states that 'tales of understanding are nothing more than wishful thinking' (Krippendorf, 1990 cited in Litvin, 2000: pp. 526). This statement is reasonable if we think of cruise tourism, mass tourism, shopping tourism and a whole other range of types of tourism, that not necessarily foster understanding between hosts and visitors. Therefore it can only be carefully stated that some forms of tourism can encourage understanding among culturally different people, and thus contribute to peace.

\section{The Broad Concept of Peace through Tourism}

The IIPT states that Peace through Tourism is not only about fostering understanding, but is also related to poverty alleviation, preservation of heritage, protection of the environment, and thus sustainability. This last statement could perhaps be a crucial point to critically asses this 
proposition; is Peace through Tourism really an "umbrella" for all these actions? To clarify this statement an analysis of tourism and its relation to poverty alleviation, protection of the environment, and preservation of heritage is made.

\section{Poverty Alleviation}

Tourism being an economic activity highly reliant on local service has a great potential as a tool to reduce poverty in worse off regions. The tourism sector provides employment opportunities for workers with low education levels, migrants from economically depressed regions, and notably favors women (accounting for $60 \%$ of the employees of hotels and restaurants) (ILO, 2007). Furthermore the creation of tourism related jobs in developing countries helps create economic opportunities in rural areas (WTO, 2006b). Tourism activities encourage infrastructure development, improving local people's living standards (WTO, 2006b).

Portrayed in this way, tourism seems to be a wonderful poverty alleviation tool, but this assumption needs to be made carefully. Tourism related jobs represent employment opportunities for non-educated people, but the kind of jobs offered to the non-skilled worker are not exactly a dream job. 'Working conditions in hotels and restaurants are largely characterized by irregular, often unsocial working hours; a-typical forms of employment such as on-call employment or undesired part time employment; comparatively low pay, little job stability and poor career prospects' (ILO, 2007: pp. $\mathrm{n} / \mathrm{a}$ ). Not all types of tourism enterprises benefit the poor, tourism can be argued to be a private sector interest driven industry and not necessarily an activity always suited to relief poverty (Bennett, Roe \& Ashley, 1999). In order to help the poor it is necessary to enhance the positive impacts of tourism and reduce its downsides employing strategies adapted to the reality of each country (Bennett, Roe \& Ashley, 1999). Some of the strategies needed to enhance the benefits of tourism for the poor are: promoting local enterprises opportunities to support local ownership of tourism operations, providing hospitality related training to local people, and securing the participation of the poor community in tourism related decisions and policy making among others (see PPTP, 2005 and Ashley, Roe \& Godwing, 2001).

Although the relationship between poverty alleviation and tourism can be regarded as positive (assuming that tourism is managed adequately to benefit the poor), there is no mention of its relation to peace found in pro-poor tourism literature. According to the Peace through Tourism writing, the pursuit of peace is not only directed to the eradication of war but also, to address poverty, injustice, and inequity among other issues (Kelly, 2006a). Considering the positive peace definition, it would be correct to affirm that the alleviation of poverty can lead to peace given that poverty is a form of passive violence. However, the analysis of poverty alleviation and its relation to peace brings back the issue that Litvin (1998) brought up about Peace through Tourism: is poverty alleviation through tourism a condition that fosters peace? Considering that tourism benefits from peaceful conditions, and that consciously planned tourism fosters poverty alleviation (which can be considered as positive peace), it could be then concluded that tourism is both a beneficiary and a creator of peace. Perhaps this last appreciation is what the working concept of Peace through Tourism for educators needs: an explanation of the peace dynamics in tourism, not tourism as a creator or beneficiary of peace, but as a process unlocking and creating opportunities for peace making.

\section{Protection of the Environment}

Tourism relies on the preservation of the environment as an irreplaceable asset to the attractiveness of a destination. Clean beaches, 'intact' natural areas and beautiful natural landscapes are characteristics that tourists search for. Conversely, uncontrolled expansion of tourism operations can be the cause of natural resources depletion and environmental degradation. Most tourists maintain high consumption and waste generation rates when taking part of tourism activities outside of their home country or region, creating a serious problem in developing areas that have no effective means of safeguarding their environment (Neto, 2003). Mass tourism and uncontrolled tourism development are overtaking the extractive industries polluting water, producing noise, creating waste, increasing pressure on natural resources and endangered species, and degrading landscape sites in transitional ecosystems (UNEP, 2002).

However, not all tourism has these negative connotations. 'Negative impacts from tourism occur when the level of visitor use is greater than the environment's ability to cope with this use within the acceptable limits of change' (UNEP, 2002: pp. n/a). Tourism can contribute to environmental conservation through the generation of revenues such as park entry fees, user fees, taxes on sales or rental of recreation equipment, and licenses for fishing and hunting among other mechanisms, which can provide the necessary funds for conservation programs and activities (UNEP, 2002). The key for reducing the negative impacts of tourism while increasing its potential to contribute to the conservation of the environment lays in its adequate management and development planning.

Well managed tourism can contribute to environmental conservation. Yet, even when considering tourism's positive effects on the environment, a direct relationship with peace is not obvious. This relationship could be clarified bearing in mind the definition of structural violence. "Structural violence is a type of violence which may also kill but at a slower pace... when structures are built up so that some people become richer at the expense of others, we have structural violence" (Brock-Unte, 1995: pp. 321). In the view of environmental degradation representing less access to natural resources and damage to the livelihood of native habitants, it could be stated that taking care of the 
environment is also a way of contributing to positive peace. However this cannot be regarded as direct cause-effect as it is more of an indirect contribution to peace.

\section{Heritage Conservation}

The word heritage describes both material or built forms (historical monuments, architectural remains) and immaterial forms (cultural heritage: traditions, folklore, art, philosophy) (Nuryanti, 1996). Tourism is believed to contribute to built and cultural heritage conservation by encouraging the continuation of traditions and cultural expressions, and by providing economical means to conserve built heritage.

On the other hand, tourism activities can also damage cultural heritage through vandalism, littering and illegal removal or damage of cultural heritage items (UNEP, 2002). The degradation of built historical sites can take place when it is not protected or when the traditional built environment is replaced, as a result of tourism growth (UNEP, 2002). Conservation of built heritage can be achieved through well managed tourism (protecting the built environment, regulating tourism flows); but the nature and management of tourism's negative impacts on cultural heritage is a somewhat more complex issue.

Negative cultural impacts begin when tourism causes changes in value systems, loss of indigenous traditions, family relationships, and morality (UNEP, 2002). Although it is argued that through well-planned and adequately managed tourism, it is possible to reduce negative impacts; authentic cultural identity conservation cannot be guaranteed.

Original cultural characteristics and authenticity are important assets for tourism, as tourists tend to search for 'authentic experiences' (Xie, 2003). However, tourism activities involve interaction between hosts and guests, interactions that have a reciprocal effect on the culture of both visitors and hosts. In variable degrees, tourists leave their prints not only on the physical environment but also on the socio-cultural life of the communities they visit (Kariel \& Kariel, 1982). The modification of original cultural expressions to fit the taste or demand of the tourists is called commodification, and it has originated a great debate about the concept of authenticity and cultural change in tourism.

For example, Maori cultural representations in New Zealand have incorporated some historical inaccuracies into their stage rituals for tourists, because a great portion of cultural products are being managed by non-Maori people (Xie, 2003 and Barnett, 1997). However, there are authors that state that if it 'weren't for [the performance of ritual and traditions for] tourism, half of Maori culture would be gone' (Shannon, 1995 cited in Xie, 2003: pp. 7). This case evidences the problem with the discussion of cultural authenticity loss in tourism. Nonetheless it is not in the scope of this article to solve the issue of authentic cultural conservation or commodification of culture as results of tourism, but only to clarify the positive and negative effects of tourism on heritage conservation and its relation to peace.

Establishing a direct relationship between the conservation of heritage and peace is not an easy task. D' Amore (1988) argues that the definition of positive peace needs the contribution of the "cultural community and the full range of creative arts forms for a spirit of celebration in cultural diversity' (pp. 152). If cultural diversity conservation is taken into account as a form of positive peace then the link between peace and heritage conservation can be found. Conversely, this is a complex relation and it requires further explanation and consideration, providing that not even the relationship between tourism and cultural heritage conservation can be stated to be completely positive.

\section{A Working Definition of Peace through Tourism for Educators}

After reviewing the notion of peace through tourism, a model of a working concept is proposed in figure 1 as a conceptual framework for educators.

- Tourism does not have a strict causal or beneficial relationship with peace; it is both a contributor and beneficiary of peace. The interaction of tourism and peace is symbiotic, one benefits from the other (1), (2), 3), (4), (8)

- Intercultural understanding is only likely to happen under 3 conditions: the traveler is conscious and interested in experimenting the culture in the destination; the hosts are willing to interact and share their culture; and the tourism activity has a small scale (1)

- Tourism can only be a means for poverty alleviation, heritage conservation, and environmental protection through adequate management and planning (it is implied that this would lead to a sustainable form of tourism), and thus contribute to positive peace (5), (6), (7) 


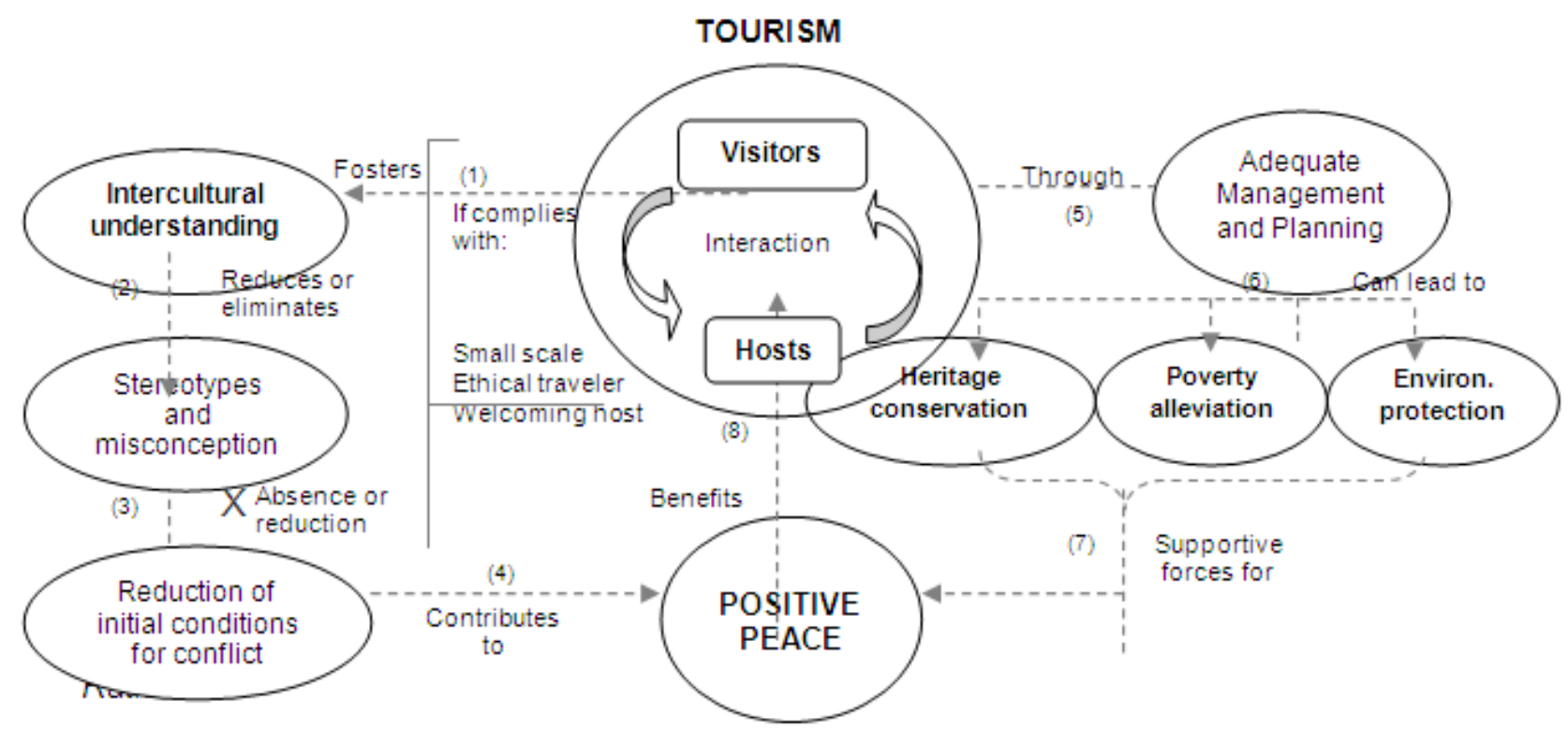

Figure 1. Working concept of Peace through Tourism for educators

\section{Challenges Lying Ahead}

It is relatively easy to clarify the role of tourism promoting peace through intercultural understanding. However, tourism educators need a definition that builds upon scientific arguments and evidence. For this purpose it is necessary to support the notion of cultural understanding promoting peace with the help of psychological arguments, referring to the impact of intercultural contact and experimentation on perceived stereotypes and behavior. Additionally it is necessary to recur to the theories of contact and attitude change, and find scientific fundaments supporting the notion of Peace through Tourism. In doing so, a deeper explanation of the role of cultural understanding and stereotypes change needs to be made in regards to theories of conflict prevention and resolution, conducting research applied to real life case studies.

It is also important to better explain the mechanisms through which environmental protection, poverty alleviation, and heritage protection contribute to peace. It cannot simply be justified by adopting the 'positive peace' definition (as done in this article for the lack of peace-related literature concerning these subjects), there is a need to further explore and identify clear links between environmental protection, poverty alleviation, and heritage protection with peace. This task will involve not only tourism educators but also tourism scientists, whom will need to come up with scientific studies supporting the idea of Peace through Tourism, to make this concept an acceptable scientific field in tourism education. Performing this task will be a notable contribution to the understanding and managing of tourism for the better, given the powerful nature of this expanding industry.

\section{Conclusion}

The 'broad' definition of Peace through Tourism can be in fact a working definition, if the relationship of tourism and peace is explained as reciprocal and not only as causal. Tourism is not strictly a contributor or a beneficiary of peace, there is a symbiotic relationship in which both benefit each other. On the other hand, although it was possible to establish a connection between positive peace and poverty alleviation, environmental protection, and heritage conservation, it is necessary to examine and research the ways in which these three dimensions work towards contributing to positive peace with further formal research. Special attention must be paid, when researching cultural heritage conservation and its relation to peace, since this topic has proven to be complex. In addition, it is necessary to identify and investigate the mechanisms through which understanding actually leads to peace thoroughly, supporting this research with theories of conflict resolution, psychology, and human behavior.

\section{REFERENCES}

[1] Anson, C. (1999), 'Planning for Peace: The Role of Tourism in the Aftermath of Violence', Journal of Travel Research, 38, pp 57-61

[2] Ashley, C, Roe, D \& H, Goodwin (2001) Pro-Poor Tourism Strategies: Expanding Opportunities for the Poor, Pro-Poor Tourism Partnership, viewed 16 March 2007, http://www.odi.org.uk/rpeg/research/pro-poor_tourism/publi cations/ppt_briefing.pdf

[3] Barnett, S. (1997), 'Maori tourism', Tourism Management, 18(7), pp. 471-473

[4] Bennett, O, Roe, D \& C, Ashley, (1999), Sustainable tourism and poverty elimination: a report for the Department of International Development, Deloitte \& Touche, International Institute for Environment and Development and Overseas Development Institute (ODI), viewed 16 March 2007, 
http://www.propoortourism.org.uk/dfid_report.pdf

[5] Brock-Utne, B. (1995), 'Educating all for positive peace: education for positive peace or oppression?', International Journal of Educational Development, 15(3), pp.321-331

[6] CES, (2004), What Happened to Yugoslavia? The War, the Peace and the Future,

[7] Center for European Studies, UNC- Chapel Hill, viewed on 2 April 2007, http://www.unc.edu/depts/europe/teachingresour ces/balkan-crisis.pdf

[8] Cho, M. (2006), 'A re-examination of tourism and peace: The case of the Mt. Gumgang tourism development on the Korean Peninsula', Tourism Management, (on line, received 14 October 2005; accepted 16 April 2006)

[9] Crotts, J. (2003), 'Theoretical perspectives on tourist criminal victimization', The Journal of Tourism Studies, 14(1), pp. 92-98

[10] Darby, J (1995) 'Conflict in Northern Ireland: A Background Essay', in, Dunn, Seamus. (ed.) (1995), Facets of the Conflict in Northern Ireland, London: Macmillan Press Ltd. Chapter available on line, viewed 12 March 2007, http://cain.ulst.ac.uk/othelem/facets.htm\#chap2

[11] D'Amore, L. J. (1988). Tourism--A Vital Force for Peace, Annals of Tourism Research, 15, pp. 269-283 Guo, Y., Kim, S., Timothy, D. \& K. Wang (2006), 'Tourism and reconciliation between Mainland China and Taiwan', Tourism Management, 27, 997-1005

[12] Higgins-Desbiolles, F. (2003), 'Reconciliation Tourism: Tourism healing divided societies!', Tourism Recreation Research, 28(3), pp. 355-44

[13] Horencyk, G. \& Z. Bekerman (1997), 'The effects of intercultural acquaintance and structured intergroup interaction on ingroup, outgroup, and reflected ingroup stereotypes', International Journal of Intercultural Relations, 21(1), pp. 71-83

[14] IIPT, (2006), Mission Statement, International Institute for Peace through Tourism, viewed 15 March 2007, http://www.iipt.org/

[15] ILO, (2007), Hotels, Catering; Tourism, International Labour Organization, viewed 21 March 2007, http://www.ilo.org/pu blic/english/dialogue/sector/sectors/tourism.htm

[16] Jafari, J. (1989), Tourism and peace, Annals of Tourism Research, 16(6), pp. 439-443

[17] Kariel, H. \& P. Kariel, (1982), 'Socio-Cultural Impacts of Tourism: An Example from the Austrian Alps', Geografiska Annaler. Series B, Human Geography, 64(1), pp. 1-16

[18] Kelly, I. (2006a), Introduction to Peace through Tourism, IIPT Occasional Paper No.1, viewed 20 February, 2007, http://www.iipt.org/educators/OccPap01.pdf

[19] Kelly, I. (2006b), The peace proposition: tourism as a tool for attitude change, IIPT Occasional Paper No.9 viewed 20 February 2007, http://www.iipt.org/educators/OccPap09.pdf

[20] Kim Y. \& J. Crompton (1990), Role of tourism in unifying the two Koreas, Annals of Tourism Research,17,pp. 353-366

[21] Kim, S. \& B. Prideaux, (2006), 'An investigation of the relationship between South Korean domestic public opinion, tourism development in North Korea and a role for Tourism in promoting peace on the Korean peninsula', Tourism Management, 27, pp. 124-137

[22] Litvin, S. (1998), 'Tourism: The World's Peace Industry?', Journal of Travel Research, 37(1), pp. 63-66

[23] Litvin, S. (2000), 'Revisiting Tourism and Understanding', Annals of Tourism Research, 27(2), pp. 526-529

[24] Neto, F. (2003), 'A new approach to sustainable tourism development: Moving beyond environmental protection', Natural Resources Forum, 27, pp. 212-222

[25] NITB, (1997), Tourism Facts 1997, Northern Ireland Tourist Board, viewed 5 March 2006, http://cain.ulst.ac.uk/ni/touris $\mathrm{m} /$ tourism1.htm\#table1

[26] NITB, (2002), Northern Ireland Annual Abstract of Statistics 2002, Northern Ireland Tourist Board, viewed 5 March 2007, http://cain.ulst.ac.uk/ni/tourism.htm\#ni-tou-02

[27] Noy, C. (2004), 'This trip really changed me, Backpackers' Narratives of Self-Change', Annals of Tourism Research, 31(1), pp. 78-102

[28] Nuryanti, W. (1996), 'Heritage tourism and postmodern tourism', Annals of Tourism Research, 23(2), pp. 249-260

[29] PPTP, 2005, Pro-Poor Tourism, Pro-Poor Tourism Partnership, viewed 14 March 2007, http://www.propoortour ism.org.uk/

[30] Ryan C., Robertson E. Page S. \& G. Kearsley (1996), Northern Ireland, tourism and peace, TourismManagement, 1 7(1), pp. 51-69

[31] Sandy, L. \& R. Perkins, (2002), 'The Nature of Peace and Its Implications for Peace Education', The Online Journal of Peace and Conflict Resolution, 4(2), pp 1-8

[32] Sonmez, S. F., Apostolopoulos, Y. \& Tarlow, P. (1999), 'Tourism in crisis: Managing the effects of terrorism. (Special issue on war, terrorism, tourism: Times of crisis and recovery)', Journal of Travel Research, 38(1), pp.3-9

[33] Spencer-Rodgersa, J \& , T. McGovern (2002), Attitudes toward the culturally different: the role of intercultural communication barriers, affective responses, consensual stereotypes, and perceived threat, International Journal of Intercultural Relations 26, pp. 609-631

[34] UN, (2002), Federal Republic of Yugoslavia Country Profile, United Nations, Johannesburg Summit 2002, viewed 2 April 2007, http://www.un.org/esa/agenda21/natlinfo/wssd/yugosl avia.pdf

[35] UNEP, (2002), Sustainable Development of TourismImpacts of Tourism: Environmental, Socio-cultural, Economic aspects, United Nations Environmental Program, viewed15 March 2007, http://www.uneptie.org/pc/tourism/s ust-tourism/

[36] WTO, (2005), Tourism Market Trends, 2004 Edition - World Overview \& Tourism Topics, World Tourism Organization, Madrid

[37] WTO, (2006a), Getting to the true value of tourism, World Tourism Organization, on line, viewed 10 March 2007, http://www.world-tourism.org/newsroom/Releases/2006/nov ember/pr58.htm 
[38] WTO, (2006b) Why tourism?, World Tourism Organization, viewed 14 March 2007, http://www.world-tourism.org/about wto/eng/menu.html
[39] Xie, P. (2003), 'The Bamboo-beating Dance in Hainan, China: Authenticity and Commodification', Journal of Sustainable Tourism, 11(1), pp. 5-16 